\title{
Multiple origins of melanism in two species of North American tree squirrel (Sciurus)
}

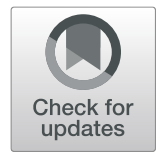

Helen R. McRobie ${ }^{1 *}$ D, Nancy D. Moncrief ${ }^{2}$ and Nicholas I. Mundy ${ }^{3}$

\begin{abstract}
Background: While our understanding of the genetic basis of convergent evolution has improved there are still many uncertainties. Here we investigate the repeated evolution of dark colouration (melanism) in eastern fox squirrels (Sciurus niger; hereafter "fox squirrels") and eastern gray squirrels (S. carolinensis; hereafter "gray squirrels").

Results: We show that convergent evolution of melanism has arisen by independent genetic mechanisms in two populations of the fox squirrel. In a western population, melanism is associated with a 24 bp deletion in the melanocortin-1-receptor gene (MC1R 24 allele), whereas in a south-eastern population, melanism is associated with a point substitution in the agouti signalling protein gene causing a Gly121Cys mutation. The MC1RA24 allele is also associated with melanism in gray squirrels, and, remarkably, all the MC1RN24 haplotypes are identical in the two species. Evolutionary analyses show that the MC1RN24 haplotype is more closely related to other MC1R haplotypes in the fox squirrel than in the gray squirrel. Modelling supports the possibility of gene flow between the two species.

Conclusions: The presence of the MC1R 24 allele and melanism in gray squirrels is likely due to introgression from fox squirrels, although we cannot completely rule out alternative hypotheses including introgression from gray squirrels to fox squirrels, or an ancestral polymorphism. Convergent melanism in these two species of tree squirrels has evolved by at least two and probably three different evolutionary routes.
\end{abstract}

Keywords: Adaptive introgression, Melanism, Melanocortin-1-receptor, Agouti signalling protein, Sciurus carolinensis, Sciurus niger, Convergent evolution

\section{Background}

The origin of adaptive genetic variation is one of the key issues in evolutionary biology. Such variation generally depends on new mutations or standing variation. Another less well understood means of adaptation is adaptive introgression where interspecific mating occurs followed by generations of backcrossing and selection for advantageous introgressed alleles. Hybridisation between closely related species has been widely documented, but the role of such hybridisation in adaptation is not always clear. Adaptive introgression has been recognised for some time as an important source of genetic variation in plants, for example between sunflower species [1], between iris species [2], and between ragwort and groundsel [3]. Until recently, there were fewer convincing examples in animals, an early case being between species of Australian fruit fly [4]. More recent examples include an allele at the $K$ locus

\footnotetext{
* Correspondence: helen.mcrobie@anglia.ac.uk

'School of Life Sciences, Anglia Ruskin University, Cambridge CB1 1PT, UK Full list of author information is available at the end of the article
}

leading to melanism that introgressed from domestic dogs to wolves [5], the $v k o r c 1$ allele that confers resistance to rat poison among Old World mice [6], variation at agouti $(A S I P)$ associated with winter coat colour in snowshoe hares [7], alleles that affect beak shape in Darwin's finches $[8,9]$, and loci controlling colour patterns in Heliconius butterflies [10].

Colouration in animals has a wide range of adaptive functions including concealment, signalling, protection and thermoregulation [11]. Melanism (darkened colouration) is found in many diverse species and two of its major functions are to provide camouflage from predators, e.g. in lizards [12] and rock pocket mice [13] and to give a thermal advantage, e.g. in butterflies, ladybirds, snails and snakes $[10,14]$. In amniote vertebrates, variation in dark colouration is primarily caused by variation in the amount of black/brown eumelanin present. Of the more than 300 loci which control melanin pigmentation in vertebrates [15], two key interacting loci have been found to be repeatedly involved in adaptive variation in 
melanin colouration: the melanocortin-1 receptor $(M C 1 R)$ gene and agouti signalling protein $(A S I P)$ gene. High activity of the MC1R protein leads to enhanced synthesis of eumelanin, a process that is inhibited by ASIP, so that gain-of-function mutations of $M C 1 R$ or loss-of-function mutations in ASIP lead to melanism [16, 17]. In wild populations, mutations in MC1R have been associated with melanism in lizards [12], $\sim 10$ species of birds $[18,19]$ and a variety of mammals, from rodents [13] to cats [20, 21]. Mutations in ASIP have been associated with melanism in birds [22], rodents [23], hares [7] and cats [21, 24].

The fox squirrel and gray squirrel are naturally sympatric over a broad region of eastern North America (Fig. 1) and have similar ecological requirements and life histories [25]. Like many species of wild mammals, individual hairs on the dorsum of these squirrels usually have alternating bands of brown/black (eumelanin) and red/yellow (phaeomelanin) pigments, a pelage condition known as "agouti." The overall appearance of coat colour for a particular animal depends on the width and placement of the pigment bands along the hair shafts as well as the intensity of the pigments. Coat colour of individuals for some wild mammals, such as the gray squirrel, is relatively uniform over the geographic distribution of the species. Other species, including the fox squirrel, exhibit dramatic patterns of geographic variation in coat colour. There are two distinct colour groups of fox squirrels: animals from most of the range (colour group 1 ), have an overall orange agouti colouration, whereas animals from the south-eastern coastal plain (colour group 2) are generally silver-gray or tan agouti with black heads and white noses and ears (Fig. 2). The colour group 1 (orange agouti) squirrels generally have intense reddish bands of phaeomelanin in their dorsal hairs; whereas the gray/tan agouti (colour group 2) animals generally have dilute yellowish bands.

Melanism (uniform dark brown or black colouration over the whole body) occurs at low frequency (less than $1 \%$ ) across most of the range of both fox squirrels and gray squirrels $[26,27]$. In this study, squirrels are characterized as jet-black melanic if their entire coat has solid jet-black hairs, as partial melanic if their coat has between 75 and $90 \%$ solid jet-black hairs, and as brownblack melanic if their coat is overall darkened, with banding on the hairs (Fig. 2). Melanism in the gray squirrel is much more common in the northern part of the range (more than 75\%) [26]; in contrast, melanism in fox squirrels is more common in the southern part of the range, reaching a maximum frequency of $13 \%$ [27]. We previously reported that a $24 \mathrm{bp}$ deletion in the
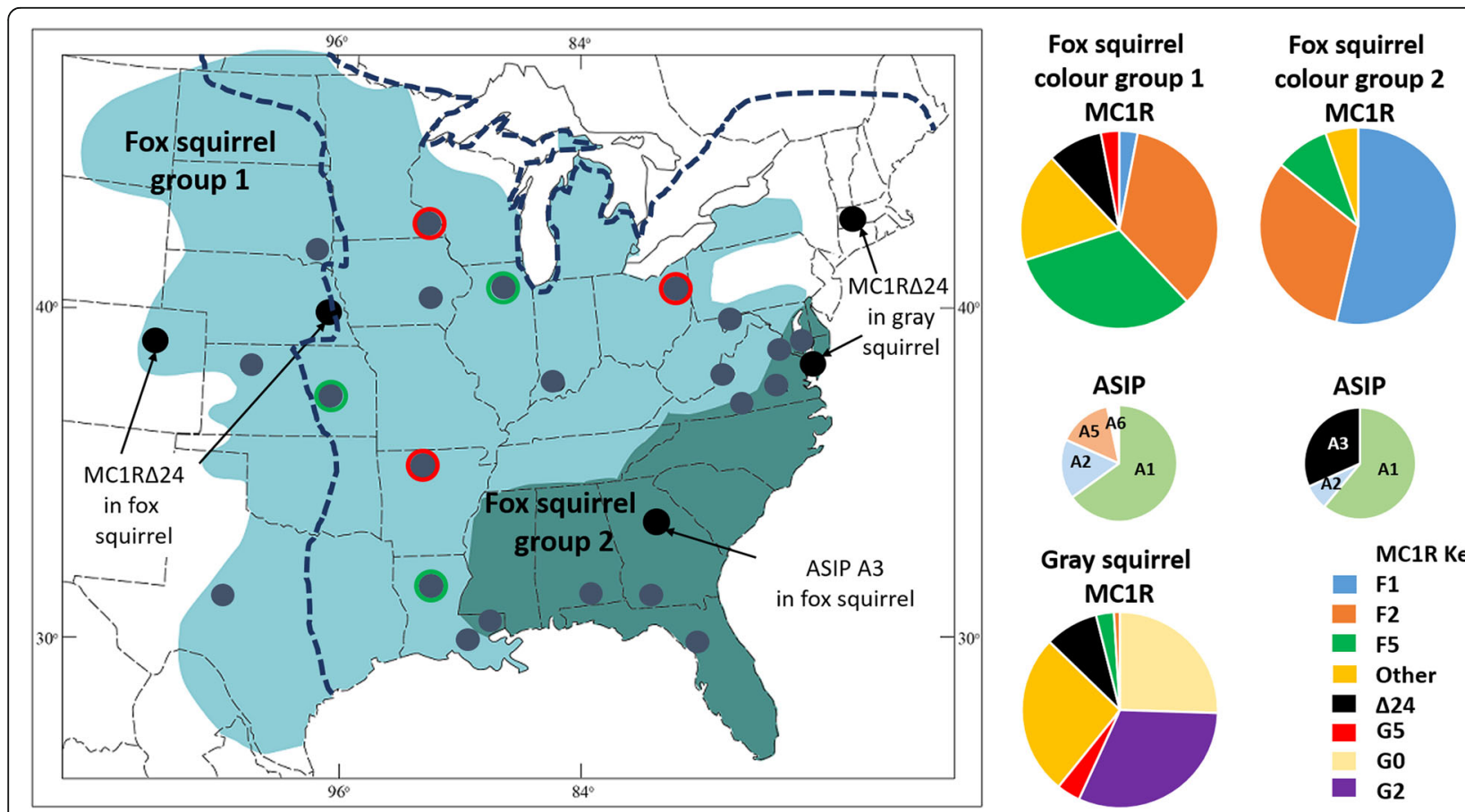

Fig. 1 Map of North America showing the native ranges fox squirrels and gray squirrels. Ranges of fox squirrel colour group 1 (orange agouti) are shown in light blue and colour group 2 (gray/tan agouti) in dark green. Gray squirrel range is to the east and south of the heavy dashed line. Spots show the locations of fox squirrel and gray squirrel samples, gray spots = wildtype, and black spots = samples with both wildtype and melanic fox squirrels or gray squirrels. Spots with coloured outlines show locations of fox squirrels with MC1R alleles typically from the gray squirrel (red outline) and locations of gray squirrels with MC1R alleles typically from the fox squirrel (green outline). Pie charts show MC1R haplotype frequencies in the fox squirrel and gray squirrel and ASIP genotype frequencies (see Additional file 3) in the fox squirrel 


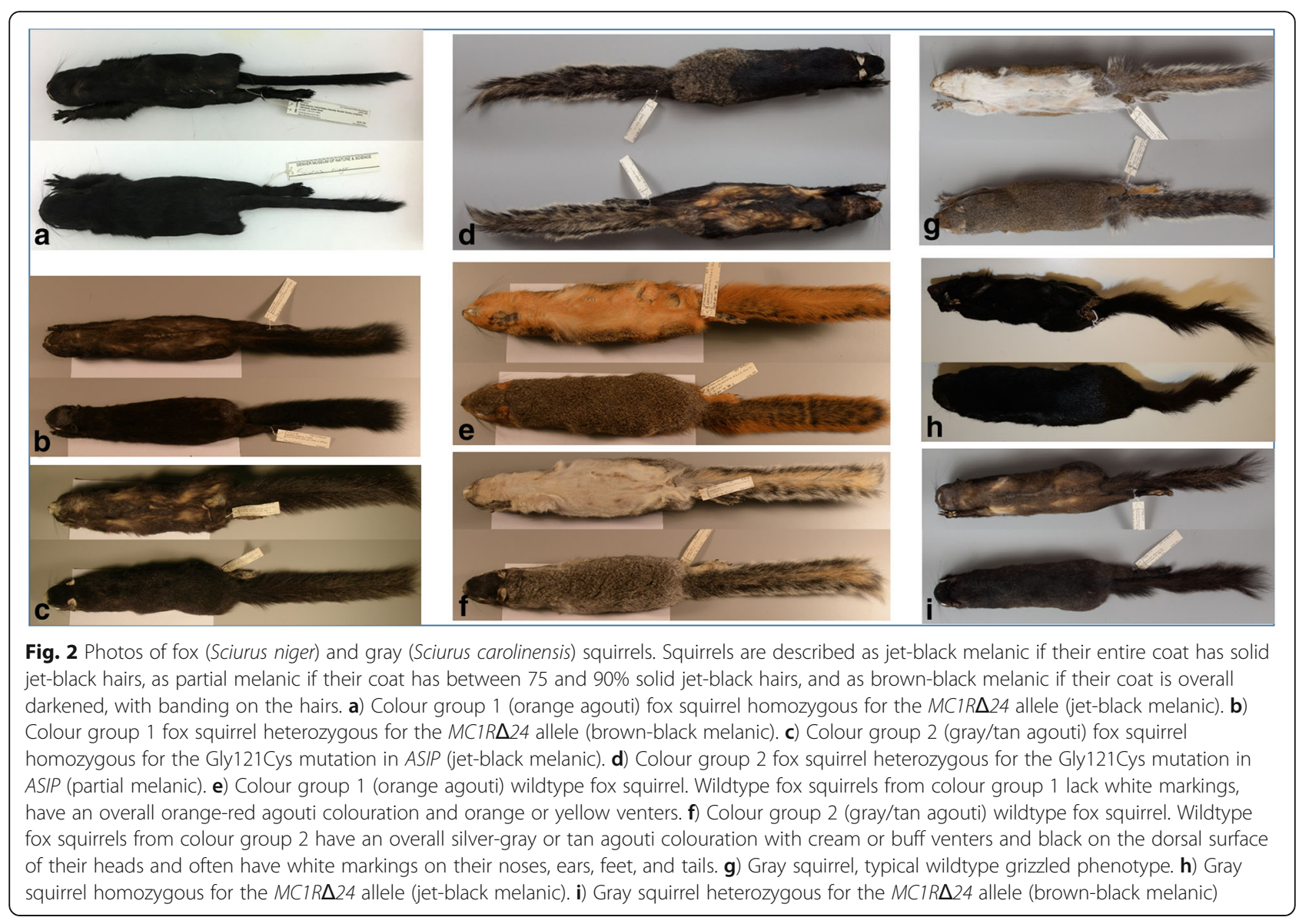

$M C 1 R$ is associated with melanism in the gray squirrel, where homozygotes for the mutation are jet-black melanic, heterozygotes are brown-black melanic, and squirrels homozygous or heterozygous for other alleles have a typical grizzled wildtype phenotype (Fig. 2) [28]. The genetic basis of melanism in the fox squirrel has not yet been elucidated.

The aim of this study was to investigate the genetic basis of melanism in the two colour groups of the fox squirrel, using a candidate gene approach. Having found that the same 24 bp deletion in the $M C 1 R$, which had previously been described in the gray squirrel, was also associated with melanism in the colour group 1 (orange agouti) fox squirrel, the study was expanded to examine the causes of derived allele sharing between the two species. Here we present evidence of multiple genetic origins of adaptive melanism in two species of tree squirrels.

\section{Results}

An allele at the $M C 1 R$ locus with a 24 bp deletion $(M C 1 R \triangle 24)$ is associated with melanism in colour group 1 (orange agouti) fox squirrels from Colorado and Nebraska. One jet-black melanic squirrel was homozygous and seven brown-black melanic squirrels were heterozygous for the
$M C 1 R \Delta 24$ allele, whereas all other colour group 1 fox squirrels $(n=42)$ had other alleles (Fisher's exact test, $P<10^{-11}$ ) (Table 1). An MC1R allele with the same $24 \mathrm{bp}$ deletion was previously found to be associated with melanism in the gray squirrel [28]. We therefore compared MC1R variation in fox squirrels to that from an expanded sample of gray squirrels $(n=51)$ (Table 1 and Additional file 1 ).

Remarkably, all $M C 1 R$ haplotypes containing the $24 \mathrm{bp}$ deletion are identical in the two species (allele counts 9 in fox squirrels and 9 in gray squirrels), and this includes gray squirrel populations introduced to British Columbia, Canada in the early 1900's and gray squirrels introduced to Britain from North America in the late 1800's [29]. On a haplotype network, the MC1R $\triangle 24$ allele is nested within the alleles from fox squirrels, a minimum of 4 mutational steps away from all other common alleles in gray squirrels (Fig. 3, Additional file 1). Most other alleles form speciesspecific clusters, but rare alleles in both species are also shared. Bayesian modelling of gene flow with a two population model (Table 2, Additional file 2) shows consistent estimation of a low degree of bi-directional gene flow between the two species, with estimates of gene flow in both directions significantly greater than zero (at $p<0.01$ ) in all runs (e.g. run 1: gray to fox, LLR 
Table 1 Samples used in this study. S. is Sciurus

\begin{tabular}{|c|c|c|c|c|c|c|}
\hline Species & Sample ID & $\begin{array}{l}\text { Colour } \\
\text { Group }\end{array}$ & Location & Phenotype & MC1R genotype & $\begin{array}{l}\text { ASIP } \\
\text { genotype }\end{array}$ \\
\hline S. niger & NDM 2380 & 2 & Southern Georgia & Partial melanic & $\mathrm{F} 1 / \mathrm{F} 2$ & $\mathrm{~A} 1 / \mathrm{A} 3$ \\
\hline S. niger & NDM 2382 & 2 & Southern Georgia & Partial melanic & $\mathrm{F} 1 / \mathrm{F} 2$ & $\mathrm{~A} 1 / \mathrm{A} 3$ \\
\hline S. niger & NDM 2383 & 2 & Southern Georgia & Partial melanic & $\mathrm{F} 1 / \mathrm{F} 1$ & $\mathrm{~A} 1 / \mathrm{A} 2$ \\
\hline S. niger & NDM 2386 & 2 & Southern Georgia & Partial melanic & $\mathrm{F} 1 / \mathrm{F} 1$ & $\mathrm{~A} 1 / \mathrm{A} 1$ \\
\hline S. niger & NDM 2953 & 2 & Southern Georgia & Partial melanic & $\mathrm{F} 1 / \mathrm{F} 1$ & A2/A3 \\
\hline S. niger & NDM 2378 & 2 & Southern Georgia & Wild-type & $\mathrm{F} 1 / \mathrm{F} 2$ & $\mathrm{~A} 1 / \mathrm{A} 1$ \\
\hline S. niger & NDM 2379 & 2 & Southern Georgia & Wild-type & $\mathrm{F} 1 / \mathrm{F} 2$ & $\mathrm{~A} 1 / \mathrm{A} 1$ \\
\hline S. niger & NDM 2389 & 2 & Southern Georgia & Wild-type & $\mathrm{F} 1 / \mathrm{F} 1$ & $\mathrm{~A} 1 / \mathrm{A} 1$ \\
\hline S. niger & NDM 2396 & 2 & Southern Georgia & Wild-type & F1/F6 & $\mathrm{A} 1 / \mathrm{A} 1$ \\
\hline S. niger & NDM 2400 & 2 & Southern Georgia & Wild-type & $\mathrm{F} 1 / \mathrm{F} 2$ & $\mathrm{~A} 1 / \mathrm{A} 1$ \\
\hline S. niger & NDM 2955 & 2 & Southern Georgia & Wild-type & $\mathrm{F} 1 / \mathrm{F} 2$ & $\mathrm{~A} 1 / \mathrm{A} 1$ \\
\hline S. niger & NDM 1624 & 2 & Northern Georgia & Jet black & $\mathrm{F} 1 / \mathrm{F} 1$ & A3/A3 \\
\hline S. niger & NDM 1627 & 2 & Northern Georgia & Jet black & $\mathrm{F} 1 / \mathrm{F} 1$ & $\mathrm{~A} 3 / \mathrm{A} 3$ \\
\hline S. niger & NDM 1526 & 2 & Northern Georgia & Wild-type & $\mathrm{F} 1 / \mathrm{F} 1$ & $\mathrm{~A} 1 / \mathrm{A} 1$ \\
\hline S. niger & NDM 1539 & 2 & Northern Georgia & Wild-type & F1/F2 & $\mathrm{A} 1 / \mathrm{A} 1$ \\
\hline S. niger & NDM 1544 & 2 & Northern Georgia & Wild-type & $\mathrm{F} 1 / \mathrm{F} 2$ & $\mathrm{~A} 1 / \mathrm{A} 1$ \\
\hline S. niger & NDM 1550 & 2 & Northern Georgia & Wild-type & $\mathrm{F} 1 / \mathrm{F} 2$ & $\mathrm{~A} 1 / \mathrm{A} 1$ \\
\hline S. niger & NDM 1551 & 2 & Northern Georgia & Wild-type & $\mathrm{F} 2 / \mathrm{F} 2$ & $\mathrm{~A} 1 / \mathrm{A} 2$ \\
\hline S. niger & NDM 1553 & 2 & Northern Georgia & Wild-type & $\mathrm{F} 1 / \mathrm{F} 1$ & $\mathrm{~A} 1 / \mathrm{A} 1$ \\
\hline S. niger & NDM 1575 & 2 & Northern Georgia & Wild-type & F1/F2 & $\mathrm{A} 1 / \mathrm{A} 2$ \\
\hline S. niger & NDM 1589 & 2 & Northern Georgia & Wild-type & $\mathrm{F} 1 / \mathrm{F} 2$ & $\mathrm{~A} 1 / \mathrm{A} 2$ \\
\hline S. niger & NDM 1519 & 2 & Northern Georgia & Partial melanic & $\mathrm{F} 1 / \mathrm{F} 1$ & $\mathrm{~A} 1 / \mathrm{A} 3$ \\
\hline S. niger & NDM 1585 & 2 & Northern Georgia & Partial melanic & $\mathrm{F} 1 / \mathrm{F} 1$ & $\mathrm{~A} 2 / \mathrm{A} 3$ \\
\hline S. niger & NDM 1616 & 2 & Northern Georgia & Partial melanic & $\mathrm{F} 1 / \mathrm{F} 1$ & $\mathrm{~A} 1 / \mathrm{A} 3$ \\
\hline S. niger & NDM 1631 & 2 & Northern Georgia & Partial melanic & F1/F2 & $\mathrm{A} 1 / \mathrm{A} 3$ \\
\hline S. niger & NDM 1534 & 2 & Northern Georgia & Jet black & $\mathrm{F} 1 / \mathrm{F} 1$ & A3/A3 \\
\hline S. niger & NDM 1540 & 2 & Northern Georgia & Jet black & F1/F2 & A3/A3 \\
\hline S. niger & NDM 1595 & 2 & Northern Georgia & Jet black & F1/F1 & A3/A3 \\
\hline S. niger & NDM 1609 & 2 & Northern Georgia & Jet black & $\mathrm{F} 1 / \mathrm{F} 1$ & A3/A3 \\
\hline S. niger & NDM 1621 & 2 & Northern Georgia & Jet black & F1/F2 & A3/A3 \\
\hline S. niger & NDM 1641 & 2 & Northern Georgia & Jet black & $\mathrm{F} 1 / \mathrm{F} 1$ & A3/A3 \\
\hline S. niger & NDM 1545 & 2 & Northern Georgia & Wild-type & F1/F2 & $\mathrm{A} 1 / \mathrm{A} 1$ \\
\hline S. niger & NDM 1642 & 2 & Northern Georgia & Jet black & $\mathrm{F} 1 / \mathrm{F} 2$ & A3/A3 \\
\hline S. niger & NDM 1535 & 2 & Northern Georgia & Wild-type & $\mathrm{F} 1 / \mathrm{F} 3$ & $\mathrm{~A} 1 / \mathrm{A} 1$ \\
\hline S. niger & NDM 1563 & 2 & Northern Georgia & Wild-type & $\mathrm{F} 1 / \mathrm{F} 1$ & \\
\hline S. niger & NDM 1570 & 2 & Northern Georgia & Wild-type & F1/F2 & $\mathrm{A} 1 / \mathrm{A} 1$ \\
\hline S. niger & NDM 1607 & 2 & Northern Georgia & Wild-type & $\mathrm{F} 1 / \mathrm{F} 1$ & $\mathrm{~A} 1 / \mathrm{A} 1$ \\
\hline S. niger & NDM 1612 & 2 & Northern Georgia & Wild-type & $\mathrm{F} 1 / \mathrm{F} 2$ & $\mathrm{~A} 1 / \mathrm{A} 3$ \\
\hline S. niger & NDM 1614 & 2 & Northern Georgia & Wild-type & $\mathrm{F} 1 / \mathrm{F} 1$ & $\mathrm{~A} 1 / \mathrm{A} 1$ \\
\hline S. niger & NDM 1617 & 2 & Northern Georgia & Wild-type & F2/F3 & $\mathrm{A} 1 / \mathrm{A} 1$ \\
\hline S. niger & NDM 1622 & 2 & Northern Georgia & Wild-type & F1/F3 & $\mathrm{A} 1 / \mathrm{A} 2$ \\
\hline S. niger & NDM 1629 & 2 & Northern Georgia & Wild-type & $\mathrm{F} 2 / \mathrm{F} 2$ & $\mathrm{~A} 1 / \mathrm{A} 1$ \\
\hline S. niger & NDM 2232 & 1 & lowa & Wild-type & $\mathrm{F} 4 / \mathrm{F} 4$ & $\mathrm{~A} 1 / \mathrm{A} 1$ \\
\hline
\end{tabular}


Table 1 Samples used in this study. S. is Sciurus (Continued)

\begin{tabular}{|c|c|c|c|c|c|c|}
\hline Species & Sample ID & $\begin{array}{l}\text { Colour } \\
\text { Group }\end{array}$ & Location & Phenotype & MC1R genotype & $\begin{array}{l}\text { ASIP } \\
\text { genotype }\end{array}$ \\
\hline S. niger & NDM 2233 & 1 & lowa & Wild-type & $\mathrm{F} 4 / \mathrm{F} 2$ & $\mathrm{~A} 1 / \mathrm{A} 1$ \\
\hline S. niger & NDM 2229 & 1 & Kansas & Wild-type & $\mathrm{F} 2 / \mathrm{F} 3$ & $\mathrm{~A} 1 / \mathrm{A} 1$ \\
\hline S. niger & NDM 1711 & 1 & Maryland & Wild-type & F2/F5 & $\mathrm{A} 1 / \mathrm{A} 1$ \\
\hline S. niger & NDM 4304 & 1 & Nebraska & Brown black & $\Delta 24 / F 2$ & $\mathrm{~A} 1 / \mathrm{A} 1$ \\
\hline S. niger & NDM 4305 & 1 & Nebraska & Brown black & $\Delta 24 / F 2$ & $\mathrm{~A} 1 / \mathrm{A} 1$ \\
\hline S. niger & NDM 3612 & 1 & South Dakota & Wild-type & F2/F5 & $\mathrm{A} 1 / \mathrm{A} 1$ \\
\hline S. niger & NDM 3613 & 1 & South Dakota & Wild-type & $\mathrm{F} 2 / \mathrm{F} 4$ & $\mathrm{~A} 1 / \mathrm{A} 1$ \\
\hline S. niger & NDM 3615 & 1 & South Dakota & Wild-type & F2/F5 & $\mathrm{A} 1 / \mathrm{A} 1$ \\
\hline S. niger & NDM 1780 & 1 & Virginia & Wild-type & $\mathrm{F} 2 / \mathrm{F} 2$ & $\mathrm{~A} 2 / \mathrm{A} 2$ \\
\hline S. niger & NDM 2196 & 1 & Virginia & Wild-type & $\mathrm{F} 2 / \mathrm{F} 2$ & $\mathrm{~A} 2 / \mathrm{A} 2$ \\
\hline S. niger & NDM 1782 & 1 & Virginia & Wild-type & $\mathrm{F} 2 / \mathrm{F} 5$ & $\mathrm{~A} 1 / \mathrm{A} 1$ \\
\hline S. niger & NDM 1783 & 1 & Virginia & Wild-type & $\mathrm{F} 2 / \mathrm{F} 2$ & $\mathrm{~A} 1 / \mathrm{A} 1$ \\
\hline S. niger & NDM 2193 & 1 & Virginia & Wild-type & $\mathrm{F} 2 / \mathrm{F} 5$ & $\mathrm{~A} 1 / \mathrm{A} 2$ \\
\hline S. niger & NDM 2194 & 1 & Virginia & Wild-type & $\mathrm{F} 2 / \mathrm{F} 2$ & $\mathrm{~A} 1 / \mathrm{A} 1$ \\
\hline S. niger & NDM 1682 & 1 & Virginia & Wild-type & $\mathrm{F} 3 / \mathrm{F} 2$ & $\mathrm{~A} 2 / \mathrm{A} 2$ \\
\hline S. niger & NDM 1790 & 1 & Virginia & Wild-type & $\mathrm{F} 1 / \mathrm{F} 2$ & $\mathrm{~A} 1 / \mathrm{A} 1$ \\
\hline S. niger & NDM 2211 & 1 & Virginia & Wild-type & $\mathrm{F} 2 / \mathrm{F} 2$ & $\mathrm{~A} 1 / \mathrm{A} 1$ \\
\hline S. niger & NDM 1426 & 2 & Alabama & Wild-type & $\mathrm{F} 1 / \mathrm{F} 1$ & \\
\hline S. niger & NDM 1460 & 2 & Maryland & Wild-type & $\mathrm{F} 5 / \mathrm{F} 5$ & \\
\hline S. niger & NDM 1464 & 2 & Maryland & Wild-type & F2/F5 & \\
\hline S. niger & NDM 1469 & 2 & Maryland & Wild-type & $\mathrm{F} 2 / \mathrm{F} 5$ & \\
\hline S. niger & NDM 1483 & 2 & Maryland & Wild-type & $\mathrm{F} 2 / \mathrm{F} 2$ & \\
\hline S. niger & NDM 1485 & 2 & Maryland & Wild-type & F2/F7 & \\
\hline S. niger & NDM 1486 & 2 & Maryland & Wild-type & F2/F5 & \\
\hline S. niger & NDM 1490 & 2 & Maryland & Wild-type & F2/F5 & \\
\hline S. niger & NDM 1744 & 1 & Indiana & Wild-type & F5/F5 & \\
\hline S. niger & NDM 1753 & 1 & Indiana & Wild-type & F5/F5 & \\
\hline S. niger & NDM 1762 & 1 & Illinois & Wild-type & $\mathrm{F} 5 / \mathrm{F} 5$ & \\
\hline S. niger & NDM 1763 & 1 & Illinois & Wild-type & $\mathrm{F} 4 / \mathrm{F} 4$ & \\
\hline S. niger & NDM 2214 & 1 & Kansas & Wild-type & $\mathrm{F} 4 / \mathrm{F} 2$ & \\
\hline S. niger & NDM 2215 & 1 & Kansas & Wild-type & F2/F5 & \\
\hline S. niger & NDM 2216 & 1 & Kansas & Wild-type & $\mathrm{F} 4 / \mathrm{F} 4$ & \\
\hline S. niger & NDM 2217 & 1 & Kansas & Wild-type & F2/F5 & \\
\hline S. niger & NDM 2218 & 1 & Kansas & Wild-type & $\mathrm{F} 5 / \mathrm{F} 5$ & \\
\hline S. niger & NDM 2219 & 1 & Kansas & Wild-type & $\mathrm{F} 2 / \mathrm{F} 5$ & \\
\hline S. niger & NDM 2220 & 1 & Kansas & Wild-type & F4/F5 & \\
\hline S. niger & NDM 2221 & 1 & Kansas & Wild-type & F4/F5 & \\
\hline S. niger & NDM 2222 & 1 & Kansas & Wild-type & F2/F5 & \\
\hline S. niger & NDM 2228 & 1 & Kansas & Wild-type & $\mathrm{F} 2 / \mathrm{F} 2$ & \\
\hline S. niger & NDM 2243 & 1 & Texas & Wild-type & $\mathrm{F} 1 / \mathrm{F} 1$ & \\
\hline S. niger & NDM 2244 & 1 & Texas & Wild-type & $\mathrm{F} 5 / \mathrm{F} 10$ & \\
\hline S. niger & NDM 2245 & 1 & Texas & Wild-type & F11/F5 & \\
\hline S. niger & NDM 2246 & 1 & Texas & Wild-type & F5/F5 & \\
\hline
\end{tabular}


Table 1 Samples used in this study. S. is Sciurus (Continued)

\begin{tabular}{|c|c|c|c|c|c|c|}
\hline Species & Sample ID & $\begin{array}{l}\text { Colour } \\
\text { Group }\end{array}$ & Location & Phenotype & MC1R genotype & $\begin{array}{l}\text { ASIP } \\
\text { genotype }\end{array}$ \\
\hline S. niger & NDM 2248 & 1 & Texas & Wild-type & F11/F5 & \\
\hline S. niger & NDM 2249 & 1 & Texas & Wild-type & F5/F5 & \\
\hline S. niger & NDM 3331 & 2 & Virginia & Wild-type & F5/F5 & \\
\hline S. niger & NDM 3354 & 2 & Virginia & Wild-type & F2/F5 & \\
\hline S. niger & NDM 3364 & 2 & Virginia & Wild-type & F5/F7 & \\
\hline S. niger & NDM 3660 & 2 & Virginia & Wild-type & $\mathrm{F} 2 / \mathrm{F} 2$ & \\
\hline S. niger & NDM 3661 & 2 & Virginia & Wild-type & $\mathrm{F} 2 / \mathrm{F} 2$ & \\
\hline S. niger & VT 1076 & 1 & Minnesota & Wild-type & G5/F5 & \\
\hline S. niger & NDM 1052 & 1 & Louisiana & Wild-type & F5/F5 & \\
\hline S. niger & NDM 1053 & 1 & Louisiana & Wild-type & F2/F3 & \\
\hline S. niger & NDM 1277 & 1 & Louisiana & Wild-type & F5/F9 & \\
\hline S. niger & NDM 1322 & 2 & Louisiana & Wild-type & $\mathrm{F} 1 / \mathrm{F} 2$ & \\
\hline S. niger & DMNS 14926 & 1 & Colorado & Brown black & $\Delta 24 / F 2$ & A5/A2 \\
\hline S. niger & DMNS 14406 & 1 & Colorado & Jet black & $\Delta 24 / \Delta 24$ & $\mathrm{~A} 1 / \mathrm{A} 1$ \\
\hline S. niger & DMNS 14268 & 1 & Colorado & Brown black & $\Delta 24 / F 2$ & A6/A1 \\
\hline S. niger & DMNS 14170 & 1 & Colorado & Brown black & $\Delta 24 / F 2$ & $\mathrm{~A} 1 / \mathrm{A} 1$ \\
\hline S. niger & DMNS 17421 & 1 & Colorado & Brown black & $\Delta 24 / F 2$ & $\mathrm{~A} 6 / \mathrm{A} 1$ \\
\hline S. niger & DMNS 17359 & 1 & Colorado & Brown black & $\Delta 24 / F 2$ & $\mathrm{~A} 1 / \mathrm{A} 1$ \\
\hline S. niger & OMNH 46253 & 1 & Ohio & Melanic ${ }^{a}$ & G5/F5 & A5/A5 \\
\hline S. niger & OMNH 46667 & 1 & Arkansas & Melanic $^{a}$ & G5/F5 & A5/A5 \\
\hline S. carolinensis & AG1 & & Washington DC & Wild-type & G0/G9 & \\
\hline S. carolinensis & AG2 & & British Columbia & Wild-type & $\mathrm{G} 2 / \mathrm{G} 2$ & \\
\hline S. carolinensis & AG3 & & British Columbia & Wild-type & $\mathrm{G} 2 / \mathrm{G} 2$ & \\
\hline S. carolinensis & AG4 & & British Columbia & Wild-type & $\mathrm{G} 2 / \mathrm{G} 2$ & \\
\hline S. carolinensis & AB1 & & Massachusetts & Jet black & $\Delta 24 / \Delta 24$ & \\
\hline S. carolinensis & $\mathrm{AB} 2$ & & British Columbia & Brown black & $\mathrm{G} 2 / \Delta 24$ & \\
\hline S. carolinensis & AB3 & & British Columbia & Brown black & $\mathrm{G} 2 / \Delta 24$ & \\
\hline S. carolinensis & AB4 & & British Columbia & Brown black & $\mathrm{G} 2 / \Delta 24$ & \\
\hline S. carolinensis & AB5 & & British Columbia & Brown black & $\mathrm{G} 1 / \Delta 24$ & \\
\hline S. carolinensis & AB6 & & British Columbia & Brown black & $\mathrm{G} 1 / \Delta 24$ & \\
\hline S. carolinensis & NDM 1497 & & Virginia & Brown black & $\mathrm{G} 2 / \Delta 24$ & \\
\hline S. carolinensis & NDM 1498 & & Virginia & Brown black & $\mathrm{G} 1 / \Delta 24$ & \\
\hline S. carolinensis & NDM 2757 & & Virginia & Wild-type & G1/G2 & \\
\hline S. carolinensis & NDM 2819 & & Virginia & Wild-type & $\mathrm{G} 2 / \mathrm{G} 7$ & \\
\hline S. carolinensis & NDM 3818 & & Virginia & Wild-type & $\mathrm{G} 1 / \mathrm{G} 2$ & \\
\hline S. carolinensis & NDM 1420 & & Alabama & Wild-type & G0/G0 & \\
\hline S. carolinensis & NDM 1421 & & Alabama & Wild-type & G0/G0 & \\
\hline S. carolinensis & NDM 1422 & & Alabama & Wild-type & G2/G7 & \\
\hline S. carolinensis & NDM 1423 & & Alabama & Wild-type & G0/G2 & \\
\hline S. carolinensis & NDM 1525 & & Georgia & Wild-type & $\mathrm{G} 2 / \mathrm{G} 0$ & \\
\hline S. carolinensis & NDM 1591 & & Georgia & Wild-type & $\mathrm{G} 2 / \mathrm{G} 4$ & \\
\hline S. carolinensis & NDM 1592 & & Georgia & Wild-type & $\mathrm{G} 2 / \mathrm{G} 0$ & \\
\hline S. carolinensis & NDM 1593 & & Georgia & Wild-type & G0/G4 & \\
\hline
\end{tabular}


Table 1 Samples used in this study. S. is Sciurus (Continued)

\begin{tabular}{|c|c|c|c|c|c|c|}
\hline Species & Sample ID & $\begin{array}{l}\text { Colour } \\
\text { Group }\end{array}$ & Location & Phenotype & MC1R genotype & $\begin{array}{l}\text { ASIP } \\
\text { genotype }\end{array}$ \\
\hline S. carolinensis & NDM 1633 & & Georgia & Wild-type & G9/G7 & \\
\hline S. carolinensis & NDM 1638 & & Georgia & Wild-type & GO/G0 & \\
\hline S. carolinensis & NDM 1721 & & Maryland & Wild-type & $\mathrm{G} 2 / \mathrm{G} 7$ & \\
\hline S. carolinensis & NDM 1722 & & Maryland & Wild-type & $\mathrm{G} 2 / \mathrm{G} 4$ & \\
\hline S. carolinensis & NDM 1723 & & Maryland & Wild-type & $\mathrm{G} 2 / \mathrm{G} 4$ & \\
\hline S. carolinensis & NDM 1730 & & Indiana & Wild-type & G4/G4 & \\
\hline S. carolinensis & NDM 1731 & & Indiana & Wild-type & $\mathrm{G} 2 / \mathrm{G} 4$ & \\
\hline S. carolinensis & NDM 1799 & & Virginia & Wild-type & $\mathrm{G} 2 / \mathrm{G} 0$ & \\
\hline S. carolinensis & NDM 1802 & & Virginia & Wild-type & $\mathrm{G} 2 / \mathrm{G} 0$ & \\
\hline S. carolinensis & NDM 1803 & & Virginia & Wild-type & GO/G0 & \\
\hline S. carolinensis & NDM 1813 & & Virginia & Wild-type & GO/G0 & \\
\hline S. carolinensis & NDM 1817 & & Virginia & Wild-type & G0/G2 & \\
\hline S. carolinensis & NDM 2258 & & Virginia & Wild-type & G0/G8 & \\
\hline S. carolinensis & NDM 2261 & & Virginia & Wild-type & G2/G11 & \\
\hline S. carolinensis & NDM 2330 & & Maryland & Wild-type & G0/G2 & \\
\hline S. carolinensis & NDM 2331 & & Maryland & Wild-type & G0/G2 & \\
\hline S. carolinensis & NDM 1760 & & Illinois & Wild-type & G5/F5 & \\
\hline S. carolinensis & VT 0985 & & Kansas & Wild-type & G5/F5 & \\
\hline S. carolinensis & VT 0992 & & Florida & Wild-type & G0/G7 & \\
\hline S. carolinensis & VT 0994 & & Florida & Wild-type & $\mathrm{G} 2 / \mathrm{G} 4$ & \\
\hline S. carolinensis & NDM 0485 & & Louisiana & Wild-type & $\mathrm{G} / \mathrm{G} 10$ & \\
\hline S. carolinensis & NDM 1007 & & Louisiana & Wild-type & G1/G9 & \\
\hline S. carolinensis & NDM 1008 & & Louisiana & Wild-type & G2/G9 & \\
\hline S. carolinensis & NDM 1120 & & Louisiana & Wild-type & $\mathrm{F} 2 / \mathrm{G} 5$ & \\
\hline S. carolinensis & NDM 1121 & & Louisiana & Wild-type & G5/F5 & \\
\hline S. carolinensis & NDM 1272 & & Louisiana & Wild-type & G0/G2 & \\
\hline S. carolinensis & NDM 1279 & & Louisiana & Wild-type & G0/G2 & \\
\hline S. carolinensis & NDM 1313 & & Louisiana & Wild-type & G0/G7 & \\
\hline
\end{tabular}

Melanic $^{a}$ indicates two brown-black melanic fox squirrels where the underlying genetics is unknown

$(\log$ likelihood ratio $)=13.81, p<0.01$, fox to gray, LLR $=$ 13.51, $p<0.01)$. Phylogenetic reconstructions using maximum likelihood show that the fox squirrel $M C 1 R$ alleles together with the MC1R $\triangle 24$ allele form a monophyletic clade that has $73 \%$ bootstrap support (Fig. 4).

There was no association between MC1R and melanism in colour group 2 (gray/tan agouti) fox squirrels (Table 1). Here there was an association between melanism and variation in ASIP: all nine jet-black melanic individuals, sampled from a single population in northern Georgia, were homozygous for a single bp substitution (G361T) leading to a Gly121Cys mutation, whereas all other colour group 2 individuals $(n=32)$ were heterozygous or homozygous for other alleles (Fisher's exact test: $P<10^{-10}$ ) (Table 1 and Additional file 3). There was also a strong tendency for individuals with intermediate, partial melanic colouration to be heterozygous for the Gly121Cys mutation, with a significant association across all colour group 2 squirrels (Fisher's exact test: $P<10^{-5}$ ). The associations between ASIP genotype and melanism are shown for the northern Georgia population in Fig. 5. The G361T substitution is unique to ASIP haplotype A3 (Additional file 3). A C253G substitution, causing an Arg85Gly mutation, which is also present in haplotype A3, is not associated with melanism. This is shown by haplotype A2, which has the C253G but not the G361T substitution: haplotype A2 is never seen in a jet-black squirrel, and almost all A1/A2 heterozygotes are wild-type and both A2/A3 heterozygotes are partial melanic (Table 1). Two melanic colour group 1 (orange agouti) fox squirrels, from Ohio and Arkansas, had no evidence for mutations in coding regions of the MC1R or ASIP 


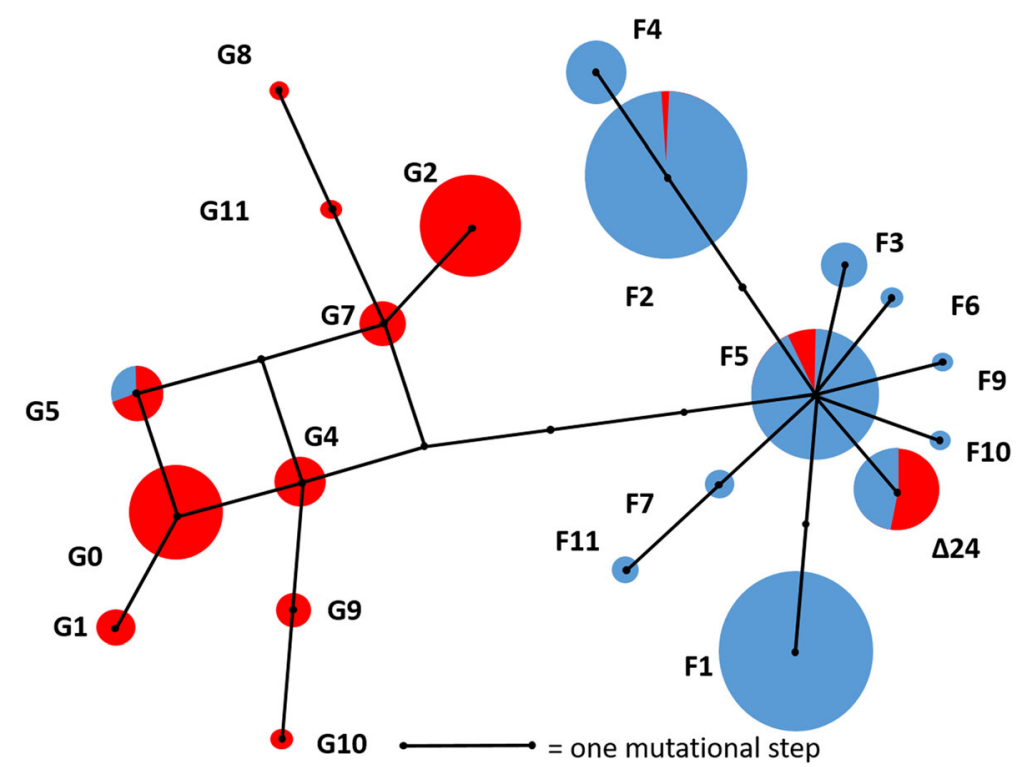

Fig. 3 Median joining MCIR haplotype network for the gray squirrel and fox squirrel. Each circle represents an allele and each line represents one or more substitutions or a deletion. Alleles from fox squirrel are blue, alleles from gray squirrel are red. Area of circles is proportional to the numbers of alleles sampled

associated with phenotype, suggesting a further genetic mechanism for melanism.

\section{Discussion}

We present strong evidence for identifying the loci underlying convergent evolution of melanism in two populations of fox squirrels. Melanism in colour group 1 (orange agouti) fox squirrels from Colorado and Nebraska is associated with the MC1R $\triangle 24$ allele identical to that found in the gray squirrel. In contrast, colour group 2 (gray/tan agouti) fox squirrels do not show an association between $M C 1 R$ and melanism (which was the basis of our previous report of a lack of association) [29], and the MC1R $\triangle 24$ allele is absent in this population. The 24 bp deletion falls at a mutational hotspot on the boundary of the second and third transmembrane domains in the MC1R receptor where a number of other species have mutations associated with melanism, for example, the bananaquit which has a E92K mutation causing the receptor to be constitutively active [30]. Functional studies on the MC1R $\Delta 24$ protein in the gray squirrel confirmed that it plausibly causes melanism - it showed high basal activity as well as responding to ASIP as an agonist in comparison to the usual inverse agonist activity of ASIP [31]. There are further examples of deletions in this part of the receptor leading to a darkened phenotype in wild populations including Eleonora's falcon, the jaguar, the jaguarundi and the golden-headed lion tamarin [20,32, 33].

We found that jet-black melanism and partial melanism in colour group 2 (gray/tan agouti) fox squirrels, are associated with a non-synonymous single nucleotide polymorphism in the ASIP locus, with all jet-black individuals being homozygous for the derived allele, and most partial melanic squirrels being heterozygous. Jetblack melanic, partial melanic, and wildtype squirrels were all sampled from the same location in northern Georgia, indicating frequent interbreeding in relation to colour phenotype. Hence population structure cannot explain this association, and this is further supported by the absence of an association between colouration and $M C 1 R$ genotype, and the overall low frequency of jetblack individuals in group 2 fox squirrels (maximum $13 \%)$. Interestingly, since there is a strong trend for heterozygous individuals to have an intermediate colour phenotype, our results are most consistent with a

Table 2 Parameter estimates from three iMa2 runs, with 95\% upper and lower posterior density bounds

\begin{tabular}{lllll}
\hline Run & Fox $\Theta$ & Gray $\Theta$ & Gene flow $\left(2 \mathrm{~N}_{\mathrm{e}} \mathrm{m}\right)$ & \multicolumn{1}{c}{$\begin{array}{l}\text { Gene flow }\left(2 \mathrm{~N}_{\mathrm{e}} \mathrm{m}\right) \\
\text { Fox to gray }\end{array}$} \\
\hline 1 & & Gray to fox & $0.31(0.077-0.49)$ \\
2 & $1.74(0.96-3.64)$ & $1.96(1.04-4.41)$ & $0.11(0.029-0.47)$ & $0.31(0.077-0.49)$ \\
3 & $1.74(0.96-3.64)$ & $1.96(1.04-4.36)$ & $0.11(0.029-0.47)$ & $0.31(0.077-0.49)$ \\
\hline
\end{tabular}




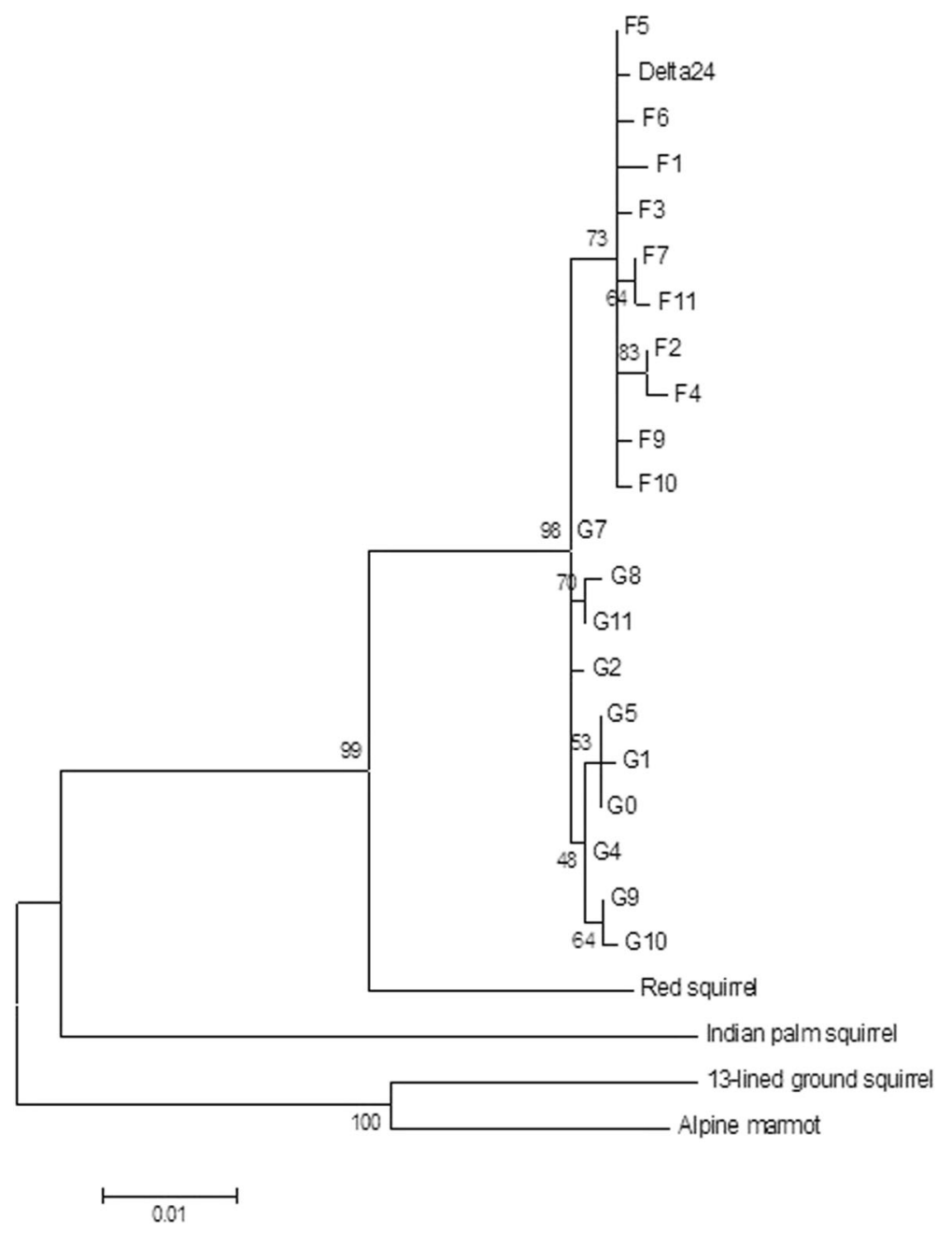

Fig. 4 Phylogenetic reconstruction of MCIR haplotypes in squirrels. Maximum likelihood reconstruction with bootstrap support values on branches, and branch lengths proportional to sequence evolution. MC1R haplotypes for fox squirrels and gray squirrels are included separately (see Fig. 3)

pattern of partial dominance at ASIP, which is unusual [34]. The Gly121Cys mutation falls in the highly conserved cysteine-rich domain of the ASIP protein, which is thought to form a highly ordered structure stabilised by five disulphide bridges that create an inhibitor cysteine-knot motif (Fig. 6 and Additional file 4) [35, 36]. The position of 10 cysteine residues in this region is highly conserved across mammalian orders, and in the four cases where changes in the number of cysteine residues have been reported, they are associated with melanism: German Shepherd dogs and alpacas (Arg96Cys) $[37,38]$, the pampas cat (Arg120Cys) [21] and the Asian golden cat (Cys128Trp) [24]. Taken together this strongly suggests that the Gly121Cys mutation in ASIP is causative for melanism in colour group 2 (gray/tan agouti) fox squirrels, although functional studies will be needed to confirm this. Our findings indicate that melanism has evolved at least twice in fox squirrels: jet-black melanic phenotypes in different parts of the species' range are the result of mutations at two different loci, MC1R and ASIP. These two loci are also associated with intraspecific events of parallel melanism in a Solomon Island flycatcher [22] and in rock pocket mice $[39,40]$. These results in tree squirrels add to the extensive evidence that $M C 1 R$ and ASIP represent functionally equivalent "adaptive hotspots" for melanism in vertebrates [18].

It is intriguing that the identical MC1R 24 haplotype is associated with melanism in both fox squirrel and gray squirrel species, and there are three possible explanations for how this has occurred. First, the allele could have arisen in the common ancestor of both species, and been retained by balancing selection. This is unlikely since deep divergences between clusters of haplotypes with and without the deletion would be expected. Second, the mutation could have arisen independently in both species, but this is also unlikely as the haplotypes are identical. Therefore the most likely explanation is that the MC1R $\Delta 24$ allele arose in one species and subsequently introgressed to the 


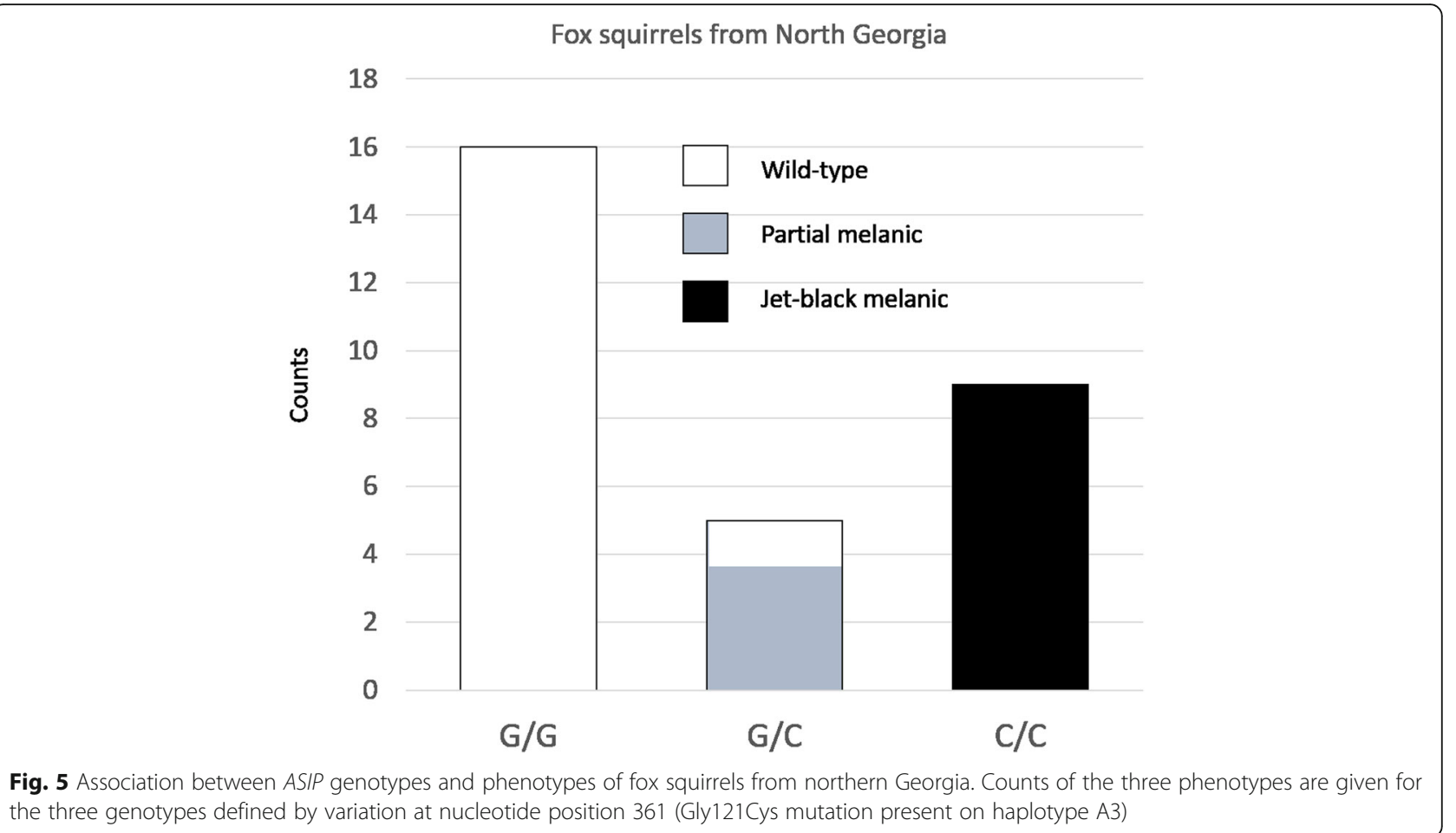

other species. Given the close association of the MC1R $\triangle 24$ allele with common fox squirrel haplotypes, and the support for monophyly of fox squirrel haplotypes including the MC1R $\triangle 24$ allele, introgression from the fox squirrel into the gray squirrel is by far the most likely scenario, but we cannot completely rule out the possibility of introgression in the other direction. The plausibility of introgression between these two sympatric species is supported by the Bayesian modelling results, although caution is needed since the results are based on a single locus, and a couple of parameters had broad posterior curves. It is notable that these squirrels have been observed in mixedspecies mating chases, with male fox squirrels pursuing female gray squirrels [41].
Interspecies mating is likely to be an important source of adaptive genetic variation. It has been noted that introgressive hybridisation has the largest evolutionary impact if two species have some morphological differences but are still closely related enough to recognise the other species as potential mates and be reproductively compatible and before the point reached when genetic incompatibilities incur severe fitness costs [8]. In such cases introgression can provide genetic variants at a higher frequency than de novo mutation, thus accelerating the evolutionary process. Unlike novel mutations, adaptive introgression has the advantage of involving alleles that have already been tested by natural selection, and so where adaptive alleles are "available" in closely

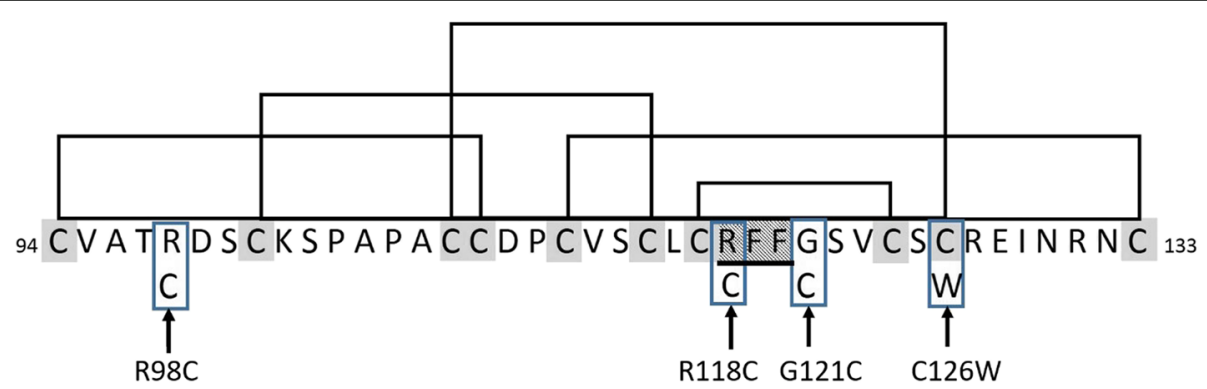

Fig. 6 Cysteine-rich domain of the agouti signalling protein. Sequence of the cysteine-rich domain of the fox squirrel (all numbering follows squirrel ASIP sequence). Disulphide bridges are shown as black lines connecting cysteines which are shaded. The bridges are predicted from those of mouse and human ASIP [36]. Mutations in the fox squirrel (Gly121Cys), dog and alpaca (Arg98Cys), [37, 38], pampas cat (Arg118Cys) [21] and Asian golden cat (Cys126Trp), [24] are boxed and highlighted with arrows. The highly conserved RFF sequence is underlined and shaded 
related species, they are likely to make an important contribution. Furthermore, dominant alleles are more likely to become established by introgression than recessive alleles, for example in $F_{1}$ individuals among the parental species where the beneficial effects of the dominant introgressed allele may counteract outbreeding depression at other loci. This is precisely the pattern found here, where dominant melanic $M C 1 R$ alleles have introgressed rather than recessive ASIP melanic alleles. It would be interesting to perform population genomic analyses on these populations to investigate the possibility of adaptive introgression of $M C 1 R$ further.

In some cases hybridization can expand the ecological niche of a population by increasing physiological tolerances beyond the range of either of the parental species $[8,42]$. This is particularly relevant where there is a new ecological challenge which may occur at the periphery of a population's range, such as a cold climate [4, 8]. For example, we suggest that the high frequency of melanic gray squirrels (with the MC1R 24 allele) in the northern parts of the species' range, which was first noted in the 1740 s by early European explorers of North America [43], might be explained by a thermogenic advantage in cold climates [44]. We also suggest that this high frequency of melanism may have contributed to the prehistoric expansion of the gray squirrel's range (during the past 11,000 years following the Wisconsinan glaciation) further north into eastern Canada. Melanism associated with the MC1R $\triangle 24$ allele may also confer thermal advantage to colour group 1 (orange agouti) fox squirrels that inhabit regions with extremely cold, harsh winters, such as Nebraska and Colorado [45]. On the other hand, melanism probably does not confer thermal advantage to colour group 1 (orange agouti) fox squirrels in the southern part of the range (lower Mississippi River drainage), because those animals rarely (if ever) experience temperatures as low as those consistently recorded in Nebraska and Colorado. Thus, the adaptive advantage for melanism appears to differ between gray squirrels and some fox squirrels, and factors responsible for melanism may differ among populations of the fox squirrel.

In addition to providing thermal advantage, melanism often functions to camouflage animals from predators $[12,13]$. To account for the higher frequency of melanism in the southern part of the fox squirrel's range, Kiltie [27] posed the hypothesis that melanism increases camouflage of colour group 2 (gray/tan agouti) fox squirrels from predators (hawks) in areas frequently burned by wildfires, such as those on the south-eastern coastal plain. He subsequently conducted a series of experiments to test concealment of all phenotypes of both fox squirrel colour groups $[46,47]$. He tested dynamic crypsis by presenting captive red-tailed hawks (Buteo jamaicensis) with moving models of melanic and wildtype phenotypes against different backgrounds (including burned and unburned tree bark) [46]. He also tested static crypsis by analysing digitized photographs to determine how well museum specimens of melanic and wildtype phenotypes matched different background types (including burned and unburned tree bark) $[45,46]$. Kiltie's experiments yielded complex results: for both colour groups, he concluded that melanism may confer concealment from hawks when fox squirrels are in motion, but wildtype colouration may be better camouflage when the animals are not moving $[46,47]$. Clearly much work remains to be done to elucidate the selective pressures on melanism in tree squirrels.

\section{Conclusions}

We conclude that the presence of the MC1RA24 allele and melanism in gray squirrels is likely due to introgression from colour group 1 (orange agouti) fox squirrels. We further conclude that melanism in colour group 2 (gray/tan agouti) fox squirrels is associated with a Gly121Cys mutation in ASIP. Finally, convergent melanism in these two species of tree squirrels has evolved by at least two and likely three different evolutionary routes $M C 1 R$ mutation, ASIP mutation, and probably introgression of $M C 1 R$ mutation.

\section{Methods}

\section{Sampling}

We used tissues and DNA samples originally collected as part of previous genetic studies of these species $[28,29,48,49]$, and we also obtained tissues from museum specimens housed at Louisiana State University Museum of Zoology, Sam Noble Oklahoma Museum of Natural History, and Denver Museum of Natural Sciences. (Note that all samples were originally collected following methods which met the guidelines of the American Society of Mammalogists for the use of mammals in research). In total we used tissue samples from 106 fox squirrels and 51 Gray squirrels from 28 locations across their ranges (see Figs. 1 and 2, Table 1). Permission was granted to import squirrel tissue to the United Kingdom from the United States of America by the Department for Environment, Food and Rural Affairs: authorisation number IMP/GEN/2014/06.

\section{Genotyping}

We extracted genomic DNA from tissue (muscle or skin) using a DNeasy Blood and Tissue Kit (Qiagen). We amplified the full coding sequence of the MC1R gene by polymerase chain reaction (PCR) using MC1R13li forward primer (TTT TCT GAG GAC AGA TCA ATG) and MC1Rer10 reverse primer (AGA ATC CAC CCT CCC TGC TC). Approximately $25 \mathrm{ng}$ template DNA was used in a total volume of $25 \mu \mathrm{l}$ with $2 \times$ MyTaq Red Mix (Bioline) and $0.4 \mu \mathrm{M}$ primers under the following 
conditions: initial denaturation $94{ }^{\circ} \mathrm{C}$ for 2 min, 30 cycles of $94{ }^{\circ} \mathrm{C}$ for $30 \mathrm{~s}, 63^{\circ} \mathrm{C}$ for $30 \mathrm{~s}$, and $72{ }^{\circ} \mathrm{C}$ for $1 \mathrm{~min}$, followed by a final extension at $72^{\circ} \mathrm{C}$ for $5 \mathrm{~min}$. We amplified all three coding exons of the ASIP gene using the following primers: exon 2: ASP2_13LF1 forward primer (5'-AGT ACT CCG CCC TCT GGA TA-3') and ASP3sqR11 reverse primer (5'-TCT GCT TCT TTT CTG CTG AT-3'), exon 3: ASPsqintron2to3F1 (5'-CCC TCT GCT CCT TCC ATT TT-3') and ASPintron3to4R1 (5'-AAT GAG AAC TCC CAG GCC TAC-3'), exon 4: ASP3to4sqF11 (5'-ATG GAC AGC TCC CGC ATT T-3') and ASP4sqrex30 (5'-AGG AAG CTT TGA GTG GAC GA-3'). PCR conditions were as for the $M C 1 R$ but with annealing temperatures as follows: exon 2, $64{ }^{\circ} \mathrm{C}$, exon $3,55^{\circ} \mathrm{C}$ and exon $4,62^{\circ} \mathrm{C}$. All PCR products were Sanger sequenced on both strands at the Department of Biochemistry, University of Cambridge.

\section{Haplotype reconstruction}

We used PHASE 2.1 [50] to reconstruct haplotypes of the $M C 1 R$, and Network [51] to generate median joining networks. All sequences have been deposited on Genbank with the following accession numbers: G0: EU604831, G1: KF188573, G2: KF188574, G4 KF188576, G5: KF188577, G7: MH043118, G8: MH043120, G9: MH043119, G10: MH043117, G11: MH043121, MC1RA24: EU604830, F1: KF052119, F2: KF052120, F3: MH043124, F4: MH043129, F5: MH043122, F6: MH043125, F7: MH043123, F9: MH043127, F10: MH043128, F11: MH043126, A1: KU724106, A2: KU724107, A3: KU724108, A4: MK780223, A5: MK780221, A6: MK780222.

\section{Phylogenetic analysis}

We used MC1R sequences of other sciurid rodents from Genbank as outgroups (red squirrel, Sciurus vulgaris, Accession KF188571; thirteen-lined ground squirrel, Ictidomys tridecemlineatus XM 005342828; Indian palm squirrel, Funambulus palmarum, KC14989; alpine marmot, Marmota marmota, XM 015495923). We used JModelTestv2.0 [52] to estimate the optimal substitution model according to Bayesian Information Criterion (BIC); the optimal model was HKY + G. Maximum likelihood reconstructions were performed in MEGA v6.0 [53], with branch support assessed using 500 bootstrap samples.

\section{Gene flow analysis}

Bayesian modelling was used to assess gene flow between fox squirrels and gray squirrels. We used iMa2 [54] to estimate gene flow at $M C 1 R$ between fox ( $n=$ $106)$ and gray $(n=39)$ squirrels in eastern USA in a two population model, ignoring the delta24 deletion. We conducted short preliminary runs to determine upper bounds for the demographic parameters and appropriate heating parameters. Then we conducted three independent runs with a different random number seed, for $10^{6} \mathrm{MCMC}$ steps and a burn-in period of $10^{5}$ steps. We used 40 chains with heating parameters -ha 0.975 , -hb 0.75. Convergence was assessed by the concordance of parameter estimates, acceptable chain mixing and autocorrelations.

\section{Additional files}

Additional file 1: "MC1R haplotypes from fox squirrels (F-) and gray squirrels (G-) with the MC1R $\Delta 24$ haplotype as reference." Table showing MC1R haplotypes. (DOCX $31 \mathrm{~kb}$ )

Additional file 2: "Marginal posterior density distributions of parameters from iMa2 analyses." Graphs showing marginal posterior density distributions of parameters from iMa2 analyses. (PPTX $51 \mathrm{~kb}$ )

Additional file 3: "ASIP haplotypes (coding sequence) from the fox squirrel (A1 - A3, A5, A6) and gray squirrel (A4) with the most common haplotype as reference." A table showing ASIP haplotypes. (DOCX 12 kb)

Additional file 4: "Alignment of ASIP protein sequences from diverse rodents and other mammalian taxa." A table showing an alignment of ASIP protein sequences from diverse rodents and other mammalian taxa. (DOCX $14 \mathrm{~kb})$

\section{Abbreviations}

ASIP: Agouti signalling protein; MC1R: Melanocortin-1-receptor gene; MC1RA24: Melanocortin-1-receptor with a 24 base pair deletion

\section{Acknowledgements}

We thank Louisiana State University Museum of Zoology, Sam Noble Oklahoma Museum of Natural History, and Denver Museum of Natural Sciences for providing samples of their specimens. We thank Anglia Ruskin University, Murray Edwards College and Virginia Museum of Natural History for funding.

\section{Authors' contributions}

HRM supervision, all laboratory work, data analysis, visualisation, drafting and coordination of writing manuscript. NDM provision of samples including data curation and contribution to writing manuscript. NIM data analysis and contribution to writing manuscript. HRM, NIM and NDM, funding acquisition. All authors have read and approved of the manuscript.

\section{Funding}

H.R.M. Anglia Ruskin University, UK. Anglia Ruskin University provided funding for H.R.M to design the study, carry out data collection and analysis, interpret the data and write the manuscript. N.I.M. Murray Edwards College, UK (data collection). N.D.M. Virginia Museum of Natural History, Martinsville, VA 24112, USA. Virginia Museum of Natural History provided funding for publication and to write the manuscript.

\section{Availability of data and materials}

All DNA sequence data is available through the publically available Genbank database.

\section{Ethics approval}

In the present study, our experimental procedures and sample collection complied with the current laws on animal welfare and research in the UK and USA and were specifically approved both the Research Ethics

Committee of Anglia Ruskin University and the Research Ethics Committee of the Virginia Museum of Natural History. The research committee of both institutions were aware that samples were used from previous studies and granted approval accordingly. All aspects of this study conform to guidelines from the Research Ethics Committee of Anglia Ruskin University. Permission was granted to import squirrel tissue to the United Kingdom from the United States of America by the Department for Environment, Food and Rural Affairs: authorisation number IMP/GEN/2014/06. 


\section{Consent for publication}

Not applicable.

\section{Competing interests}

The authors declare that they have no competing interests.

\section{Author details}

'School of Life Sciences, Anglia Ruskin University, Cambridge CB1 1PT, UK.

${ }^{2}$ Virginia Museum of Natural History, Martinsville, VA 24112, USA.

${ }^{3}$ Department of Zoology, University of Cambridge, Cambridge CB2 3EJ, UK.

Received: 10 January 2019 Accepted: 30 June 2019

Published online: 11 July 2019

\section{References}

1. Whitney K, Randell R, Reiseberg L. Adaptive introgression of herbivore resistant traits in the weedy sunflower Helianthus annuus. Am Nat. 2006;167: 230-9 https://doi.org/10.1086/504606.

2. Martin N, Bouck A, Arnold M. Detecting adaptive trait introgression between Iris fulva and I. brevicaulis in highly selective field conditions. Genetics. 2006;172:2481-9 https://doi.org/10.1534/genetics.105.053538.

3. Kim M, Cui M, Cubas P, Gillies A, Lee K, Chapman MA, Abbott RJ, Coen E. Regulatory genes control a key morphological and ecological trait transferred between species. Science. 2008;322:1116-9 https://doi.org/1 $0.1126 /$ science. 1164371 .

4. Lewontin R, Birch L. Hybridization as a source of variation for adaptation to new environments. Evolution. 1966;20:315-36 https://doi.org/10.2307/24 06633.

5. Anderson T, vonHoldt B, Candille S, Musiani M, Greco C, Stahler D, Smith D, Padhukasahasram B, Randi E, Leonard J, Bustamante C, Ostrander E, Tang H, Wayne R, Barsh G. Molecular and evolutionary history of melanism in north American gray wolves. Science. 2009;323:1339-43. https://www.ncbi.nlm.nih. gov/pmc/articles/PMC2903542/.

6. Song Y, Endepols S, Klemann N, Richter D, Matuschka F, Shih C, Nachman M, Kohn M. Adaptive introgression of anticoagulant rodent poison resistance by hybridization between old world mice. Curr Biol. 2011;21: 1296-301 https://doi.org/10.1016/j.cub.2011.06.043.

7. Jones MR, Mills LS, Alves PC, Callahan CM, Alves JM, Lafferty DJR, Jiggins FM, Jensen JDM-F, Good JM. Adaptive introgression underlies polymorphic seasonal camouflage in snowshoe hares. Science. 2018;360:1355-8.

8. Grant R, Grant P. Fission and fusion of Darwin's finches populations. Phil Trans R Soc B. 2008:363:2821-9 https://doi.org/10.1098/rstb.2008.0051.

9. Lamichhaney S, Berglund J, Almén MS, Maqbool K, Grabherr M, MartinezBarrio A, Promerová M, Rubin CJ, Wang C, Zamani N, Grant BR, Grant PR, Webster MT, Andersson L. Evolution of Darwin's finches and their beaks revealed by genome sequencing. Nature. 2015;518:371-5 https://doi.org/1 $0.1038 /$ nature 14181 .

10. Pardo-Diaz C, Salazar C, Baxter S, Merot C, Fiqueiredo-Ready W, Joron M McMillan O, Jiggins C. Adaptive introgression across species boundaries in Heliconius butterflies. PLoS Genet. 2012;8(6):e1002752. https://doi.org/10.13 71/journal.pgen.1002752.

11. Majerus M. Melanism: evolution in action. Oxford: Oxford University Press; 1998.

12. Rosenblum $\mathrm{E}$, Hoekstra $\mathrm{H}$, Nachman M. Adaptive reptile colour variation and the evolution of the MC1R gene. Evolution. 2004;58:1794-808 https://doi. org/10.1111/j.0014-3820.2004.tb00462.x.

13. Nachman MW, Hoekstra HE, D'Agostino SL. The genetic basis of adaptive melanism in pocket mice. Proc Natl Acad Sci U S A. 2003;100:5268-73 https://doi.org/10.1073/pnas.0431157100.

14. Bittner T, King R, Kerfin J. Effects of body size and melanism on the thermal biology of garter snakes (Thamnophis sirtalis). Copeia. 2002;2002:59-68.

15. Lin JY, Fisher DE. Melanocyte biology and skin pigmentation. Nature. 2007; 445:843-50 https://doi.org/10.1038/nature05660.

16. Robbins LS, Nadeau JH, Johnson KR, Kelly MA, Roselli-Rehfuss L, Baack E, Mountjoy KG, Cone RD. Pigmentation phenotypes of variant extension locus alleles result from point mutations that alter MSH receptor function. Cell. 1993;72:827-34 https://doi.org/10.1016/0092-8674(93)90572-8.

17. Abdel-Malek ZA, Scott MC, Furumura M, Lamoreux ML, Ollmann M, Barsh GS, Hearing VJ. The melanocortin 1 receptor is the principal mediator of the effects of agouti signaling protein on mammalian melanocytes. J Cell Sci. 2001;114:1019-24
18. Mundy NI. A window on the genetics of evolution: MC1R and plumage colouration in birds. Proc R Soc B. 2005:272:1633-40 https:// royalsocietypublishing.org/doi/10.1098/rspb.2005.3107

19. Janssen K, Mundy NI. The genetic basis and enigmatic origin of melanic plumage polymorphism in pomarine skuas (Stercorarius pomarinus). Proc Roy Soc B. 2017;284:20171735 https://doi.org/10.1098/rspb.2017.1735.

20. Eizirik E, Yuhki N, Johnson WE, Menotti-Raymond M, Hannah SS, O'Brien SJ. Molecular genetics and evolution of melanism in the cat family. Curr Biol. 2003;13:448-53 https://doi.org/10.1016/S0960-9822(03)00128-3.

21. Schneider S, Henegar C, Day K, Absher D, Napolitano C, Silveira L, David V O'Brien S, Menotti-Raymond M, Barsh G, Eizirik E. Recurrent evolution of melanism in south American felids. PLoS Genet. 2015;11:e1005126 https:// doi.org/10.1016/S0960-9822(03)00128-3.

22. Uy JAC, Cooper EA, Cutie S, Concannon MR, Poelstra JW, Moyle RG, Filardi CE. Mutations in different pigmentation genes are associated with parallel melanism in island flycatchers. Proc Roy Soc B. 2016;283:20160731 https:// doi.org/10.1098/rspb.2016.0731.

23. Kingsley EP, Manceau M, Wiley CD, Hoekstra HE. Melanism in Peromyscus is caused by independent mutations in Agouti. PLoS One. 2009;4:e6435 https://doi.org/10.1371/journal.pone.0006435.

24. Schneider A, David V, Johnson W, O'Brien S, Barsh G, Menotti-Raymond M, Eizirik E. How the leopard hides its spots: ASIP mutations and melanism in wild cats. PLoS One. 2012;7:e50386 https://doi.org/10.1371/journal.pone.005 0386

25. Edwards J, Ford M, Guynn D. Fox and gray squirrels. In: Wild mammals of North America: biology, management, and conservation. Baltimore: John Hopkins University Press; 2003. p. 248-67.

26. Robertson Gl. Distribution of colour morphs of Sciurus carolinensis in eastern North America. Unpublished M.S. Thesis. London: University of Western Ontario; 1973. p. 79

27. Kiltie RA. Wildfire and the evolution of dorsal melanism in fox squirrels, Sciurus niger. J Mammal. 1989;70:726-39 https://doi.org/10.2307/1381707.

28. McRobie $H$, Thomas A, Kelly J. The genetic basis of melanism in the gray squirrel (Sciurus carolinensis). J Hered. 2009:100:709-14 https://doi.org/10.1 093/jhered/esp059.

29. McRobie H, King L, Fanutti C, Coussons $P$, Moncrief N, Thomas A Melanocortin-1-receptor (MC1R) gene sequence variation and melanism in the gray (Sciurus carolinensis), fox (Sciurus niger) and red (Sciurus vulgaris) squirrel. J Hered. 2014;105:423-8 https://doi.org/10.1093/jhered/esu006.

30. Theron E, Hawkins K, Bermingham E, Ricklefs R, Mundy N. The molecular basis of an avian plumage polymorphism in the wild: a melanocortin-1receptor point mutation is perfectly associate with the melanic plumage morph of the bananaquit, Coereba flaveola. Curr Biol. 2001;11:550-7 https:// doi.org/10.1016/S0960-9822(01)00158-0.

31. McRobie HR, King LM, Fanutti C, Symmons MF, Coussons PJ. Agouti signalling protein is an inverse agonist to the wildtype and agonist to the melanic variant of the melanocortin-1 receptor in the gray squirrel (Sciurus carolinensis). FEBS Lett. 2014;588:2335-43 https://doi.org/10.1016/j.febslet.2 014.05.032.

32. Gangoso L, Grande JM, Ducrest AL, Figuerola J, Bortolotti GR, Andrés JA, Roulin A. MC1R-dependent, melanin-based colour polymorphism is associated with cell-mediated response in the Eleonora's falcon. J Evol Biol. 2011:24:2055-63 https://doi.org/10.1111/j.1420-9101.2011.02336.x.

33. Mundy NI, Kelly J. Evolution of a pigmentation gene, the melanocortin-1 receptor, in primates. Am J Phys Anthropol. 2003;121:67-80.

34. Bultman SJ, Michaud EJ, Woychik RP. Molecular characterization of the mouse agouti locus. Cell. 1992;71:1195-204 https://doi.org/10.1016/S00928674(05)80067-4.

35. Bolin KA, Anderson DJ, Trulson JA, Thompson DA, Wilken J, Kent SB, Gantz I, Millhauser GL. NMR structure of a minimized human agouti related protein prepared by total chemical synthesis. FEBS Lett. 1999:451:125-31 https://doi. org/10.1016/S0014-5793(99)00553-0.

36. McNulty JC, Jackson PJ, Thompson DA, Chai B, Gantz I, Barsh GS, Dawson PE, Millhauser GL. Structures of the agouti signaling protein. J Mol Biol. 2005;346:1059-70 https://doi.org/10.1016/j.jmb.2004.12.030.

37. Kerns JA, Newton J, Berryere TG, Rubin EM, Cheng J, Schmutz SM, Barsh GS. Characterization of the dog agouti gene and a nonagoutimutation in German shepherd dogs. Mamm Genome. 2004;15:798-808 https://doi.org/1 0.1007/s00335-004-2377-1

38. Chandramohan B, Renieri C, La Manna V, La Terza A. The alpaca agouti gene: genomic locus, transcripts and causative mutations of eumelanic and 
pheomelanic coat colour. Gene. 2013;521:303-10 https://doi.org/10.1016/j. gene.2013.03.060.

39. Nachman MW, Hoekstra HE, D'Agostino SL. The genetic basis of adaptive melanism in pocket mice. PNAS. 2003;100(9):5268-73.

40. Moore JN. Molecular variation in the agouti gene in pocket mice from the Carrizozo Malpaís lava flow. Unpublished M. S. Thesis, Tucson: University of Arizona Press; 2012. p81

41. Koprowski J. Mixed-species mating chases of fox squirrels and eastern gray squirrels. Canadian Field Naturalist, Ottawa. 1991;105:117-8 http://www. bioversitylibrary.org/item/106992

42. Svardson G. Significance of introgression in coregonid evolution. In: Biology of coregonid fishes (Ed. C.C Lindsy and C.S. woods) pp. Winnipeg: University of Manitoba Press; 1970. p. 33-59.

43. Schorger AW. Squirrels in early Wisconsin. Trans Wisconsin Acad Sci Arts Lett. Wisconsin. 1949:39:195-247.

44. Ducharme MB, Larochelle J, Richard D. Thermogenic capacity in gray and black morphs of the gray squirrel, Sciurus carolinensis. Physiol Zool. 1989;62: 1273-92. https://www.journals.uchicago.edu/doi/pdfplus/10.1086/ physzool.62.6.30156213

45. Ciurej AK. Why are melanistic fox squirrels expanding in Omaha, Nebraska? An assessment of overwinter body condition, skin temperature, and behaviour. Unpublished M. S. Thesis, Omaha: University of Nebraska; 2014. p. 42

46. Kiltie RA. Tests of hypotheses on predation as a factor maintaining polymorphic melanism in coastal-plain fox squirrels (Sciurus niger L.). Biol J Linn Soc. 1992:45:17-37 https://doi.org/10.1111/j.1095-8312.1992.tb00629.x.

47. Kiltie RA. Camouflage comparisons among fox squirrels from the Mississippi river delta. J Mammal. 1992;73(4):906-13.

48. Moncrief ND, Lack JB, Maldonado JE, Bryant KL, Edwards CW, Van Den Bussche RA. General lack of phylogeographic structure in two sympatric, forest obligate squirrels (Sciurus niger and S. carolinensis). J Mammal. 2012; 93:1247-64.

49. Moncrief ND, Lack JB, Van Den Bussche RA. Eastern fox squirrel (Sciurus niger) lack phylogeographic structure: recent range expansion and phenotypic differentiation. J Mammal. 2010;91:1112-23.

50. Stephens M, Smith NJ, Donnelly P. A new statistical method for haplotype reconstruction from population data. Am J Hum Genet. 2001;68:978-89 https://doi.org/10.1086/319501.

51. Bandelt JH, Forster P, Röhl A. Median-joining networks for inferring intraspecific phylogenies. Mol Biol Evol. 1999;16:37-48 https://doi.org/10.1 093/oxfordjournals.molbev.a026036.

52. Darriba D, Taboada Gl, Doallo R, Posada D. jModelTest 2: more models, new heuristics and parallel computing. Nat Methods. 2012;9:772.

53. Tamura K, Stecher G, Peterson D, Filipski A, Kumar S. MEGA6: molecular evolutionary genetics analysis version 6.0. Mol Biol Evol. 2013;30:2725-9.

54. Hey J. The divergence of chimpanzee species and subspecies as revealed in multipopulation isolation-with-migration analyses. Mol Biol Evol. 2000;27: 921-33 https://doi.org/10.1093/molbev/msp298.

\section{Publisher's Note}

Springer Nature remains neutral with regard to jurisdictional claims in published maps and institutional affiliations.

Ready to submit your research? Choose BMC and benefit from:

- fast, convenient online submission

- thorough peer review by experienced researchers in your field

- rapid publication on acceptance

- support for research data, including large and complex data types

- gold Open Access which fosters wider collaboration and increased citations

- maximum visibility for your research: over $100 \mathrm{M}$ website views per year

At $\mathrm{BMC}$, research is always in progress.

Learn more biomedcentral.com/submissions 